\title{
The Influence of Nitrogen Applications on Leaf Nutrient Content of Dracaena Sanderiana Hort $^{1}$
}

\author{
Saulo J. Rodríguez and Carlos Rivera López ${ }^{2}$
}

\begin{abstract}
Rooted D. sanderiana Hort. cuttings were placed in glazed 5-gal crocks in a 1:1 peatmoss-sand mixture and fertilizer containing 0,300 , $600,900,1200$, and $2400 \mathrm{lb}$. of N/acre/year was applied. Leaf samples were collected from the 4 th, 5 th, and 6 th positions in each cutting during harvesting time and analyzed for different nutrients.

$\mathrm{N}, \mathrm{P}$, and $\mathrm{K}$ contents were not markedly affected during the first harvest period. The $\mathrm{N}$ content increased markedly during the second leaf sampling. At the same time both $\mathrm{P}$ and $\mathrm{K}$ decreased. $\mathrm{Ca}$ and $\mathrm{Mg}$ contents were not affected significantly as applied $\mathrm{N}$ increased, but $\mathrm{Fe}$ decreased from the 300- to the 900-lb level of application. Beyond this level, there was a substantial increase in Fe content.
\end{abstract}

\section{INTRODUCTION}

The concept of nutrient element balance in plant nutrition and subsequent nutrient interrelationships has been reported in the literature, e.g., the classical work by Shears et al. (5) in tung tree nutrition, and several summaries have been published $(1,2,3)$. Moreover, the book edited by N. F. Childers on fruit nutirition $(6,7)$ presented summaries on the subject of leaf analysis. Shears (6) and Smith (7) established several interrelationships of different nutrients in citrus and tung nutrition, respectively. According to Smith (7) the addition of $\mathrm{N}$ causes positive effects on leaf $\mathrm{N}$ and $\mathrm{Mg}$. At the same time negative effects were observed on $\mathrm{P}, \mathrm{K}, \mathrm{Cu}, \mathrm{Zn}$, and $\mathrm{Mn}$ content of the leaves. No effects were observed in $\mathrm{Ca}$ and $\mathrm{B}$ content. Shears (6) mentioned the relationship of the three main cations in which the accumulation of one brings about a depression of the others.

The present work reports on the effect of different levels of $\mathrm{N}$ fertilization on some nutrient components of Dracaena sanderiana Hort. leaves.

${ }^{1}$ Manuscript submitted to Editorial Board November 25, 1974.

${ }^{2}$ Horticulturist and Agronomist, Plant Breeding and Service Departments, respectively, Agricultural Experiment Station, Mayagüez Campus, University of Puerto Rico, Río Piedras, P. R. 


\section{MATERIALS AND METHODS}

Five-gal glazed crocks were filled with a 1:1 mixture of Cataño sand and peatmoss. Three rooted D. sanderiana Hort. cuttings were placed in each crock. Each cutting measured 9 in $(23 \mathrm{~cm})$ in length and weighed 18 $\pm 3 \mathrm{~g}$. The plants were placed in a $47 \%$ calculated propylene shade.

Six treatments consisting of $0,300,600,900,1200$, and $2400 \mathrm{lb} /$ year of $\mathrm{N}$ were distributed in a paired-plot design. Each treatment was replicated five times. The whole experiment consisted of 30 pots. $\mathrm{P}$ and $\mathrm{K}$ were applied at a constant rate of 400 and $800 \mathrm{lb} /$ acre/year of $\mathrm{P}_{2} \mathrm{O}_{5}$ and $\mathrm{K}_{2} \mathrm{O}$, respectively.

$\mathrm{N}$ was applied as ammonium sulphate while $\mathrm{P}$ and $\mathrm{K}$ were mxied as triple superphosphate and muriate of potash, respectively. The mixture was applied three times during the year starting 1 month after planting.

Harvesting was started as soon as each plant produced a commercialsize cutting. It consisted of severing the top from each plant at $4^{1.2}$ in from the sand-peatmoss mixture.

The most recently mature leaves were separated from each cutting. Leaves from the 4th, 5 th, and 6 th positions from the top were composited for analysis (4).

All samples were analyzed using standard procedures and the data statistically evaluated.

\section{RESULTS AND DISCUSSION}

The results from the first set of samples are presented in table 1. No marked differences in the $\mathrm{N}, \mathrm{P}$, and $\mathrm{K}$ contents were observed. Nevertheless, some degree of depressive effects of $\mathrm{N}$ on $\mathrm{P}$ and $\mathrm{K}$ occurred.

Results of analysis of samples from the second harvest period are presented in table 2 . The results showed a definite dependence of leaf $\mathrm{N}$ on the $\mathrm{N}$ applied to the growth media. The lowest $\mathrm{N}$ value was obtained in the treatment with no $\mathrm{N}$ application. The highest value was obtained at the maximum quantity of $\mathrm{N}$ tested. With the $2400-\mathrm{lb}$ treatment plants were still accumulating $\mathrm{N}$ in the leaves. Concurrently with the leaf $\mathrm{N}$ accumulation, there was a reduction in $\mathrm{P}$ and $\mathrm{K}$ contents.

The $\mathrm{Ca}$ and $\mathrm{Mg}$ contents were not affected by the accumulation of $\mathrm{N}$, but the Fe content decreased from the 300 -lb level to the $900 \mathrm{lb} / \mathrm{acre} /$ year treatment with a possible synergistic effect thereafter.

The antagonistic effect of $\mathrm{N}$ application on $\mathrm{K}$ might be explained partly either by the competition of the ammonium ion until nitrification occurs or by the dilution effect due to increased growth with higher levels of $\mathrm{N}$. Thereafter, the competition might possibly be between the nitrate form and the phosphate ion. 
The lack of effect of $\mathrm{N}$ on the $\mathrm{Ca}$ and $\mathrm{Mg}$ contents while depressing $\mathrm{K}$ is intriguing. According to Shears $(5,6)$ there must be a constant cation/anion ratio. If $\mathrm{K}$ is depressed an increase in the two other main cations would be expected to maintain the above mentioned ratio.

It is concluded from these results that in $D$. sanderiana Hort., N, P, K and $\mathrm{Fe}$ contents in the leaves are modified by $\mathrm{N}$ fertilization but $\mathrm{Ca}$ and $\mathrm{Mg}$ are not.

TABLE 1. The effect of different levels of $N$ application on $N, P$, and $K$ content of Dracaena sanderiana Hort. leaves taken during first harvest period

\begin{tabular}{cccc}
\hline \multirow{2}{*}{ N rate } & \multicolumn{3}{c}{ Leaf nutrient content, dry weight basis } \\
\cline { 2 - 4 } & $\mathrm{N}$ & $\mathrm{P}$ & $\mathrm{K}$ \\
\hline Lb/acre/year & $\%$ & $\%$ & $\%$ \\
0 & $2.01 \mathrm{a}^{2}$ & $0.30 \mathrm{a}$ & $2.77 \mathrm{a}$ \\
300 & $2.06 \mathrm{a}$ & $.21 \mathrm{~b}$ & $2.69 \mathrm{ab}$ \\
600 & $2.09 \mathrm{a}$ & $.18 \mathrm{bc}$ & $2.85 \mathrm{ab}$ \\
900 & $2.09 \mathrm{a}$ & $.17 \mathrm{c}$ & $2.52 \mathrm{ab}$ \\
1200 & $2.12 \mathrm{a}$ & $.17 \mathrm{c}$ & $2.54 \mathrm{ab}$ \\
2400 & $2.43 \mathrm{a}$ & $.18 \mathrm{bc}$ & $2.39 \mathrm{~b}$ \\
\hline
\end{tabular}

${ }^{1}$ Adjusted means with letters in common not differing significantly at the $5 \%$ level.

TABLE 2.-The effect of different levels of $N$ application on several nutrient components of Dracaena sanderiana Hort. leaves taken during the second harvest period

\begin{tabular}{ccccccc}
\hline \multirow{2}{*}{ N rate } & \multicolumn{6}{c}{ Leaft nutrient content, dry weight basis } \\
\cline { 2 - 7 } & $\mathrm{N}$ & $\mathrm{P}$ & $\mathrm{K}$ & $\mathrm{Ca}$ & $\mathrm{Mg}$ & $\mathrm{Fe}$ \\
\hline Lb/acre/year & $\%$ & $\%$ & $\%$ & $\%$ & $\%$ & $\mathrm{P} / \mathrm{m}$ \\
0 & $1.96 \mathrm{c}^{1}$ & $0.26 \mathrm{a}$ & $2.57 \mathrm{a}$ & $2.87 \mathrm{a}$ & $0.49 \mathrm{a}$ & $198 \mathrm{ab}$ \\
300 & $2.77 \mathrm{ab}$ & $.16 \mathrm{~b}$ & $2.33 \mathrm{a}$ & $2.33 \mathrm{a}$ & $.33 \mathrm{a}$ & $152 \mathrm{ab}$ \\
600 & $3.17 \mathrm{ab}$ & $.18 \mathrm{ab}$ & $1.99 \mathrm{~b}$ & $2.56 \mathrm{a}$ & $.39 \mathrm{a}$ & $135 \mathrm{ab}$ \\
900 & $3.38 \mathrm{ab}$ & $.11 \mathrm{~b}$ & $1.97 \mathrm{~b}$ & $2.55 \mathrm{a}$ & $.37 \mathrm{a}$ & $95 \mathrm{~b}$ \\
1200 & $3.48 \mathrm{ab}$ & $.15 \mathrm{~b}$ & $1.66 \mathrm{~b}$ & $2.88 \mathrm{a}$ & $.42 \mathrm{a}$ & $156 \mathrm{ab}$ \\
2400 & $3.86 \mathrm{a}$ & $.19 \mathrm{~b}$ & $1.74 \mathrm{~b}$ & $2.86 \mathrm{a}$ & $.38 \mathrm{a}$ & $203 \mathrm{a}$ \\
\hline
\end{tabular}

${ }^{1}$ Adjusted means with the letters in common do not differ significantly at the $5 \%$ level.

\section{RESUMEN}

Esquejes de Dracaena sanderiana Hort. se sembraron en una mezcla de partes iguales de arena y musgo. A esta mezcla se le aplicó nitrógeno a niveles de $0,300,600,900,1,200$ y 2,400 libras por acre y año.

Luego se tomaron muestras de las hojas que ocupaban la cuarta, quinta y sexta posición en la parte joven del tallo, cuando ya los esquejes habían alcanzado un tamaño apropiado para un esqueje comercial. Estas hojas se analizaron para determinar su contenido en 
varios elementos. En la primera recolección de hojas el contenido en N, P y $\mathrm{K}$ no reflejó diferencias estadísticas. Sin embargo, en la segunda recolección, hecha en la misma forma, los análisis para N, P y K reflejaron variaciones debidas a las aplicaciones de nitrógeno. Hubo un aumento en el contenido en nitrógeno de la hoja según aumentaron los niveles de nitrógeno aplicados al medio, y una reducción simultánea en el $\mathrm{P}$ y el $\mathrm{K}$ de las hojas. El contenido en $\mathrm{Fe}$ disminuyó al principio, aumentando luego con aplicaciones sobre las 900 libras de nitrógeno. Los contenidos en Ca y $\mathrm{Mg}$ no fueron afectados significativamente.

\section{LITERATURE CITED}

1. Brown, John C., Interactions involving nutrient elements, Ann. Rev. Plant Physiol. 14: 93-106, 1963.

2. Gauch, Hugh G., Mineral nutrition of plants, Ann. Rev. Plant Physiol. 8: 31 41, 1957.

3. Reuther, Walter, Embleton, T. W., and Jones, W. W., Mineral nutrition of tree crops, Ann. Rev. Plant Physiol. 9: 175-206, 1958.

4. Rodŕguez, Saulo J., Rivera-López, Carlos, and Santiago, Alejandro, Variation in chemical composition of Dracaena sanderiana leaves as influenced by leaf maturity and shade intensity, J. Agr. Univ. P.R. 57(2): 136-48, 1973.

5. Shears, C. B., Crane, H. L., and Myers, A. T., Nutrient-element balance. A fundamental concept in plant nutrition, Proc. Amer. Soc. Hort. Sci. 47: 239-48, 1946.

6. Shears, C. B., Tung nutrition, In: N. F. Childers (ed.), "Fruit Nutrition, Temperate to Tropical”, pp. 549-68, Somerset Press, Inc., Somerville, N. J., 1966.

7. Smith, Paul F., Leaf analysis of citrus, In: N. F. Childers (ed.), "Fruit Nutrition, Tem. perate to Tropical, pp. 209-28, Somerset Press, Inc., Somerville, N. J., 1966. 